DOI: $10.17805 /$ trudy.2016.6.4

\title{
ВЗАИМОДЕЙСТВИЕ УЧАСТНИКОВ ОБРАЗОВАТЕЛЬНЫХ ОТНОШЕНИЙ, КАК ФАКТОР ФОРМИРОВАНИЯ БЕЗОПАСНОЙ ОБРАЗОВАТЕЛЬНОЙ СРЕДЫ (ДОШКОЛЬНОЕ ОБРАЗОВАНИЕ)
}

\author{
И. В. Кощиенко \\ (Московский гуманитарный университет)
}

\begin{abstract}
Аннотация: Статья посвящена проблеме безопасности образовательной среды дошкольной образовательной организации. Автором выделены современные проблемы социальных институтов - семьи и детского сада оказывающие влияние на развитие ребенка дошкольного возраста.

Ключевые слова: образовательная среда; дошкольное образование; образовательные отношения; дошкольная организация

\section{INTERACTION OF PARTICIPANTS OF THE EDUCATIONAL RELATIONS AS A FACTOR OF BUILDING SAFE EDUCATIONAL ENVIRONMENT IN PRESCHOOL EDUCATION}

\author{
I. V. Koshchiyenko \\ (Moscow University for the Humanities)
}

\begin{abstract}
The article examines the problem of safety of the educational environment in preschool education. We focus on current problems of such social institutions as family and the kindergarten which influence the development of a child in preschool age

Keywords: educational environment; preschool education; educational attitudes; preschool educational organization
\end{abstract}

Обеспечение безопасности в период дошкольного детства - одна из острейших проблем современности. Ориентация системы отечественного образования на реализацию права каждого ребенка на качественное и доступное образование привела к переосмыслению и развитию идей отношения к дошкольному образованию как первой ступени общего образования.

Прежде чем дать характеристику современной безопасной образовательной среды дошкольной организации, обозначим те угрозы, которые существуют в социальных институтах - семье и детском саду.

Во-первых, многие исследователи сегодня констатируют кризис семьи, который связан, прежде всего, с падением ценности института брака, 
a, следовательно, и родительства. Не маловажную роль играют и финансовые трудности, которые испытывают молодые семьи (особенно неполные). Нивелирована роль бабушек, в связи с объективной экономической необходимостью для семьи увеличения срока их занятости на работе. В результате: «У современных родителей нередко наблюдается нежелание вникать в проблемы ребенка, негуманный стиль воспитания, перенос собственных личностных и психологических проблем на детей» (Майер, Тимофеева, 2012: 13). Отметим, что в современных условиях родители активно стремятся «переложить» свои права и обязанности на созданную в Российской Федерации многофункциональную, развивающуюся систему общественного дошкольного образования детей.

Во-вторых, в результате формального общения родителей и педагогов (Е. П. Арнаутова, Т. А. Куликова, А. В. Хуторской и др.) происходит отчуждение образовательного учреждения и семьи, не формируются положительные, эмоционально насыщенные межличностные отношения и деловое сотрудничество между педагогами и родителями. Авторы полагают, что от методов назидания и принуждения необходимо переходить к методам сотрудничества, диалогическому взаимодействию (деятельностно-диалоговой форме взаимодействия, отмечено нами).

Как показывает практика работы современных дошкольных образовательных организаций, до сих пор сохраняется проблема деятельностнодиалогового взаимодействия педагогов и родителей. Вместо активного диалога, совместных творческих дел, проектов и др., проводятся формальные мероприятия, используются традиционные формы работы с родителями, отношения строятся на выражении взаимных претензий воспитателей и родителей друг к другу. Для того чтобы деятельностнодиалоговая форма взаимодействия стала приоритетной в процессе совместной педагогической деятельности необходимо создать в педагогическом коллективе атмосферу поиска эффективных педагогических решений, открытого, откровенного обмена мнениями.

Деятельностно-диалоговая форма сотрудничества между педагогами и родителями предполагают совместное конструирование целей, средств и способов достижения результатов, в результате чего происходит осмысление процесса целостного развития ребенка на личностном уровне. Умение диалогически взаимодействовать является показателем уровня сформированности коллектива единомышленников (педагогов и родителей).

Сегодня в условиях дошкольной образовательной организации сотрудничество педагогов с семьей становится решающим фактором создания психологически комфортной безопасной образовательной среды ребенка. В данном случае мы согласны с мнением авторов учебного пособия «Педагогика и психология ненасилия в образовании» о том, что «...задачи 
педагогики и психология ненасилия вплотную соотносятся с решением сложных задач безопасности личности» (Маралов, Ситаров, 2012: 249).

Отечественной педагогической наукой накоплен значительный опыт в сфере взаимодействия детского сада и семьи (П. П. Блонский, П. Ф. Каптерев, Н. К. Крупская, П. Ф. Лесгафт, А. С. Макаренко, В. А. Сухомлинский, С. Т. Шацкий и др.). В современной педагогике выделены основные типы, виды педагогического взаимодействия. В исследованиях Г. М. Андреевой, Л. В. Байбородовой, А. С. Белкина, Х. Й. Лийметса, В. А. Ляудиса показано многообразие факторов, влияющих на процесс взаимодействия образовательной организации и среды. В отдельных научных трудах Ш.А.Амонашвили, Г. В. Гатальской, А. А. Гина, Т. Г. Григорьевой, И. А. Зимней, Е.В.Коротаевой, П. И. Пидкасистого и др., нашло отражение осмысление педагогического взаимодействия в образовательном процессе.

Современные исследователи Е. П. Арнаутова, В. Г. Алямовская, И.Ф.Дементьева, В. П. Дуброва, Т. А. Данилина, Т. Н. Доронова, М. Г. Дрезнина, О. Л. Зверева, Т. В. Кротова, О. А. Куревина, О. В. Огороднова, Л.В. Свирская, 3. И. Теплова и др. отмечают важность сотрудничества педагогов и родителей для воспитания и развития детей дошкольного возраста.

Включение семьи как партнера и активного субъекта в образовательную среду дошкольной организации качественно изменяет условия взаимодействия педагогов и родителей, имеющих собственные стратегические интересы в сфере дошкольного образования ребенка.

Итак, задача создания безопасной, психологически комфортной образовательной среды не может быть решена без стремления педагогов и родителей найти рациональный вариант плана совместной деятельности, создание практико-ориентированной среды с целью освоения основных задач, форм и методов дошкольного образования, коммуникативной, психолого-педагогической компетентности в области развивающего взаимодействия и выработке согласованности действий педагогов и родителей в процессе всестороннего развития ребенка.

\section{СПИСОК ЛИТЕРАТУРЫ}

Майер, А. А., Тимофеева, Л. Л. (2013) Трудности стандартизации дошкольного образования // Дошкольная педагогика. № 10. С. 12-15.

Маралов, В. Г., Ситаров, В. А. (2012) Педагогика и психология ненасилия в образовании. 2-е изд., перераб. и доп. М. : Юрайт. 424 с.

Дата поступления: 12.12.2016 г.

Кощиенко Ирина Васильевна - кандидат педагогических наук, доцент кафедры педагогики и психологии высшей школы Московского гуманитарного университета. Адрес: 111395, Россия, г. Москва, ул. Юности, д. 5. Тел: +7 (499) 374-74-59. Эл. адрес: ikoschienko@mosgu.ru 
Koshchiyenko Irina Vasilyevna, Candidate of Pedagogy, Associate professor, Department of the Pedagogy and Psychology of Higher School, Moscow University for the Humanities. Postal address: 5 Yunosti St., 111395 Moscow, Russian Federation,. Tel.:+7 (499) 374-74-59. E-mail: ikoschienko@ mosgu.ru

\section{Для цитирования:}

Кощиенко И. В. Взаимодействие участников образовательных отношений, как фактор формирования безопасной образовательной среды (дошкольное образование) [Электронный ресурс] // Научные труды Московского гуманитарного университета. 2016, № 6. URL: http://journals.mosgu.ru/trudy/article/view/376 (дата обращения: дд.мМ.гг.). 